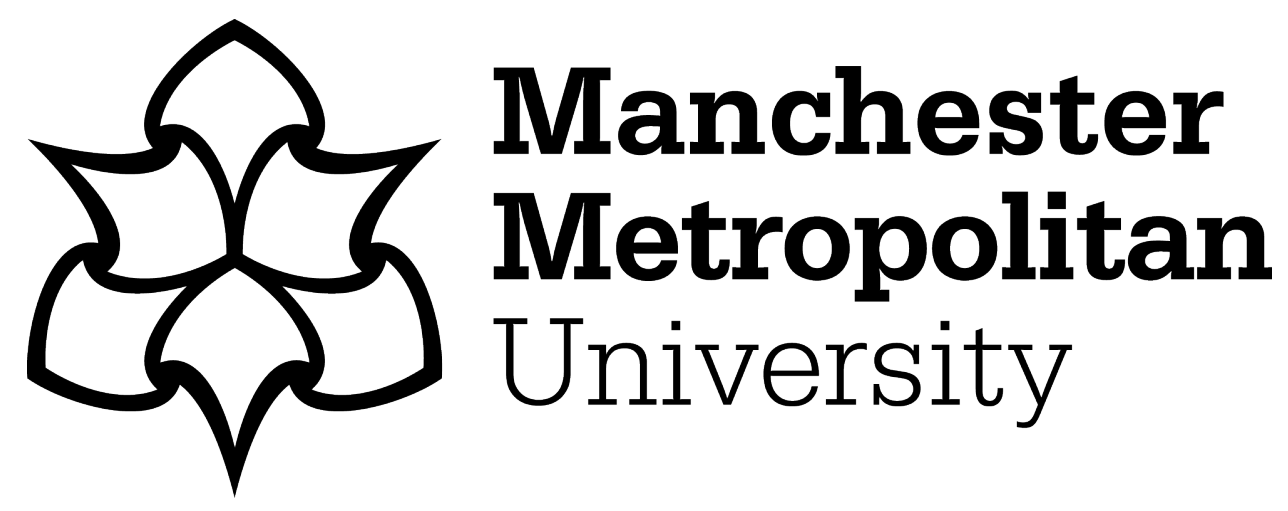

Ngo, Huyen, Pickard, Alison and Walton, Geoff ORCID logoORCID: https://orcid.org/0000-0003-4251-2891 (2019) An information literacy teaching model for Vietnam's schools. Global Knowledge, Memory and Communication, 68 (3). pp. 191-206. ISSN 2514-9342

Downloaded from: https://e-space.mmu.ac.uk/622274/

Version: Accepted Version

Publisher: Emerald

DOI: https://doi.org/10.1108/GKMC-05-2018-0047

Please cite the published version 


\section{Global Knowledge, Memory and Communi}

\section{An information literacy teaching model for Vietnam's schools}

\begin{tabular}{|r|l|}
\hline Journal: & Global Knowledge, Memory and Communication \\
\hline Manuscript ID & GKMC-05-2018-0047.R1 \\
\hline Manuscript Type: & Article \\
\hline Keywords: & $\begin{array}{l}\text { Information literacy, High school, Vietnam, Information literacy teaching } \\
\text { model, Upper secondary schools, Pedagogy }\end{array}$ \\
\hline \multicolumn{2}{|l}{} \\
\hline
\end{tabular}

\section{SCHOLARONE \\ Manuscripts}




\title{
An information literacy teaching model for Vietnam's schools
}

\begin{abstract}
Purpose - This study aims to identify the ways in which information literacy (IL) inpractice initiatives are framed for Vietnam's upper secondary students and to suggest an appropriate IL teaching model for schools in the country.
\end{abstract}

Design/methodology/approach - The research employed a qualitative multiple case study approach, including two phases of data collection. The first phase gathered data from semistructured student interviews. The second phase included semi-structured professional interviews and an analysis of documents.

Findings - The research found that time pressure, teaching method, resource issues, students' awareness of IL and support from family are challenges for the development of IL programmes. These factors contribute to the development of an IL teaching model for Vietnam's upper secondary schools.

Research limitations/implications - The focus of this study was limited to two schools in order to gain the depth of data needed to provide a holistic picture of the practice of IL teaching in Vietnam's upper secondary schools.

Practical implications - This study could provide some guidance to the Ministry of Education and Training in the development of educational policies and initiatives through identifying the possible contributions of IL to Vietnam's education system.

Originality/value - The study provides an understanding of the development of IL in the education system in transition, from a didactic to a constructivist approach.

Keywords Information literacy, High school, Vietnam, Pedagogy

Paper type Research paper

\section{Introduction}

In the educational environment, schools are striving to prepare students to meet the changes of the information environment. Despite the important role of information literacy (IL) being widely acknowledged, there is still a lack of IL programmes implemented in educational institutions (Shenton et al., 2014). This paper reports on the findings of a qualitative research which aims to identify the ways in which IL in-practice initiatives are framed for Vietnam's upper secondary students and to suggest an appropriate IL teaching model for schools in the country. 


\section{Context of the study}

The blending of three ideologies, Confucianism, Taoism and Buddhism, has contributed to the development of Vietnam's society and culture. They put the emphasis on the hierarchy of superior-inferior relationships, human suffering, and the relationship between humans and the cosmos. This has created the notable characteristics of passivity, compliance, submissiveness, acceptance of fate and maintenance of the status quo in Asian countries' culture and that of Vietnam. This creates the ideal environment for the ingrained acceptance of passive learning and the teacher-centred teaching model in Vietnam (Nguyen, 2013).

The Vietnamese believe that learning is the only path for advancement (World Bank (WB), 2011). Therefore, Vietnamese families invest more in their children's education. Additionally, the value of family is highly appreciated. This has created a lot of pressure for students. Students have to study as hard as they can to achieve good results in examinations.

Since 1986, Vietnam conducted a number of economic and political reforms called "Đổi mới” (Renovation) which allowed the Vietnamese economy to integrate into the globalised world (WB, 2014). This results in a wave of foreign investment into Vietnam. The transition sets out a requirement that workers need to be equipped with the right skills (WB, 2014). The Economic and Social Development Strategy and Human Resource Development Project 2011-2020 indicates that developing human resources to fulfil the requirements of international integration is Vietnam's focus (Prime Minister, 2011). Furthermore, in order to achieve the educational objective "Developing creativity and selflearning; and encouraging lifelong learning" (Central Committee of the Communist Party of Vietnam, 2013, p. 4), therefore for this to be realised, there is a need to employ a constructivist approach as it promotes a learner-centred learning environment, learners' independent thinking and active learning (Mayes \& de Freitas, 2013). In recent years, there have been attempts made to replace the traditional delivery mode of transmission by a constructivist approach. However, studies point out that a didactic approach remains prevalent in the education system (Nguyen and Williams, 2016). London (2011) argues that there is a significant gap between educational policies and practice. This problem could result from lacking experience and understanding to the 'Western theories' among teachers (Nguyen and Hall, 2017), their persistent beliefs on 'face saving' (Nguyen, 2015), unequal understanding and insufficient attention from local areas for education development strategy, and insufficient human resources at all levels (Ministry of Education and Training 
${ }^{1}$ By extra classes, this paper means classes which are organized by schools after official classes.

${ }^{2}$ By private classes, this paper means classes which are individually organized by teachers. 
provided by Japan International Cooperation Agency.

Integration of information and communication technology (ICT) in Vietnam's education system is being implemented to promote a student-centred teaching approach. ICT access of students and teachers was improved, but it was found that the application of ICT in teaching practice remained limited and did not satisfy the need of the education transition. ICT access at home of Vietnamese students is not high (UNESCO, 2013b).

A new general education curriculum and new textbooks are being developed to promote knowledge acquisition, active learning, and creative and critical thinking in schools. Initial drafts were published along with a call for comments from individuals, experts and organizations, the latest being issued in January 2018. Textbooks are compiled by a group of educators, scientists and education professionals who are experts in the fields of science and education, to provide knowledge with the aim of supporting teaching and learning activities. MOET is responsible for organizing and directing the implementation of this work. While student textbooks are the main learning material for students, teacher textbooks support teachers in teaching activities.

MOET oversees the operation of the school library system in Vietnam. In line with the development of the education sector, the operational content of the school library is constantly being improved. Although it is acknowledged that the school library is necessary for research, learning and teaching, school libraries have not been operated effectively. More than $50 \%$ of school libraries have not achieved the national standard for a school library (Dang, 2012). School libraries are facing many challenges, $\mathrm{Vu}$ et al. (2013) note a range of obstacles such as: funding, which is limited, the capacity of school librarians in general as the weakest in comparison with other types of libraries (limited IT and foreign language skills), the absence of school libraries in rural and mountainous areas, and the majority of school libraries operating in the traditional mode.

\section{Information literacy and its contextual and cultural nature}

IL can be interpreted and defined from different perspectives. According to Walton and Cleland (2013), the development of IL capability ensues from a broader social setting and that IL comprises three spheres, finding, evaluating and using information, and each scope activates its own set of behavioural, cognitive, metacognitive and affective elements.

Lloyd (2012, p. 772), by examining how people connect with the information landscape that forms their settings or practices, sees IL "as a socially enacted practice". The sociocultural perspective of IL views “how people's use of information cannot be 
meaningfully separated from the tools that are an integral part of social practices" (Limberg et al., 2012, p. 95). Instead of identifying IL as a set of skills, this point of view recognises IL in its relationship with the information setting, which has a strong influence on how people understand information.

Information is "connected to larger cultural, historical, social and political systems" (Norgaard et al., 2003, p. 126). Meanwhile, literacy is also a culturally situated phenomenon (Accardi et al., 2014). By bringing together 'information' and 'literacy', IL becomes a cultural concept. The cultural nature of IL has been explored in a number of recent studies because the development of IL in non-Western countries has received the attention of researchers. Based on studies on IL education in Asian countries, Dorner indicates that "the diversity in populations, politics, cultures, and levels of economic prosperity is immense and greatly affects IL and IL education across the region" (Dorner, 2017 , p. 47). It is suggested that the local context in general and local cultural norms in particular needs to be considered in order to promote the development of IL programmes (Dorner and Gorman, 2006).

An IL definition in developing countries was introduced by Dorner and Gorman (2006, p. 284) who define IL as:

The ability of individuals or groups to be aware of why, how and by whom information is created, communicated and controlled, and how it contributes to the construction of knowledge; to understand when information can be used to improve their daily living or to contribute to the resolution of needs related to specific situations, such as at work or school; to know how to locate information and to critique its relevance and appropriateness to their context; to understand how to integrate relevant and appropriate information with what they already know to new construct knowledge that increases their capacity to improve their daily living or to resolve needs related to specific situations that have arisen.

This definition emphasises the contextual and cultural nature of IL that has led to differences in IL education between Western and non-Western countries.

\section{Methodology}

This qualitative research focused on two of Vietnam's upper secondary schools, in which each school was treated as a single case. The research brought the context of each case/school at both macro and micro environment level together based on Layder's (1993) approach (Figure 1). 


\begin{tabular}{|c|c|c|}
\hline $\begin{array}{l}\text { CONTEXT - } \\
\text { MACRO } \\
\text { ENVIRONMENT }\end{array}$ & \multicolumn{2}{|c|}{$\begin{array}{l}\text { Vietnam: } \\
\begin{aligned} \text { - } & \text { Cultural and social context } \\
\text { - } & \text { Educational context } \\
\text { - } & \text { School library system } \\
\text { - } & \text { Digital access }\end{aligned}\end{array}$} \\
\hline \multirow{2}{*}{ SETTING } & \multicolumn{2}{|c|}{ Intermediate social organization } \\
\hline & $\begin{array}{l}\text { Case } 1 \text { - School B } \\
(1,146 \text { students })\end{array}$ & $\begin{array}{l}\text { Case } 2 \text { - School C } \\
\text { (981 students) }\end{array}$ \\
\hline $\begin{array}{l}\text { SITUATED } \\
\text { ACTIVITY }\end{array}$ & Learning & Learning \\
\hline SELF & $\begin{array}{l}\text { IL development - } \\
\text { students, librarians, } \\
\text { teachers, } \\
\text { administrators }\end{array}$ & $\begin{array}{l}\text { IL development - } \\
\text { students, librarians, } \\
\text { teachers, } \\
\text { administrators }\end{array}$ \\
\hline
\end{tabular}

Figure 1. The context of two schools at both macro and micro environment

The study chose the Standards for the $21^{\text {st }}$-Century Learner (American Association of School Librarians (AASL), 2007) as its theoretical framework because the focus of the model is on the K-12 education environment and students' learning. The original AASL model takes into account some of the criticisms made against other earlier models. In 2013, UNESCO introduced a Global Media and Information Literacy (MIL) Assessment Framework, but it mainly concentrates on teachers' MIL competencies in service and in training rather than students (UNESCO, 2013a). Therefore, the AASL provides a more robust model than UNESCO's at present. The expanded version of the Standards for the $21^{\text {st }}$-Century Learner, as illustrated in Figure 2 (see XXXXXXX for further details), was used to examine the practice of IL teaching and learning in the schools. 


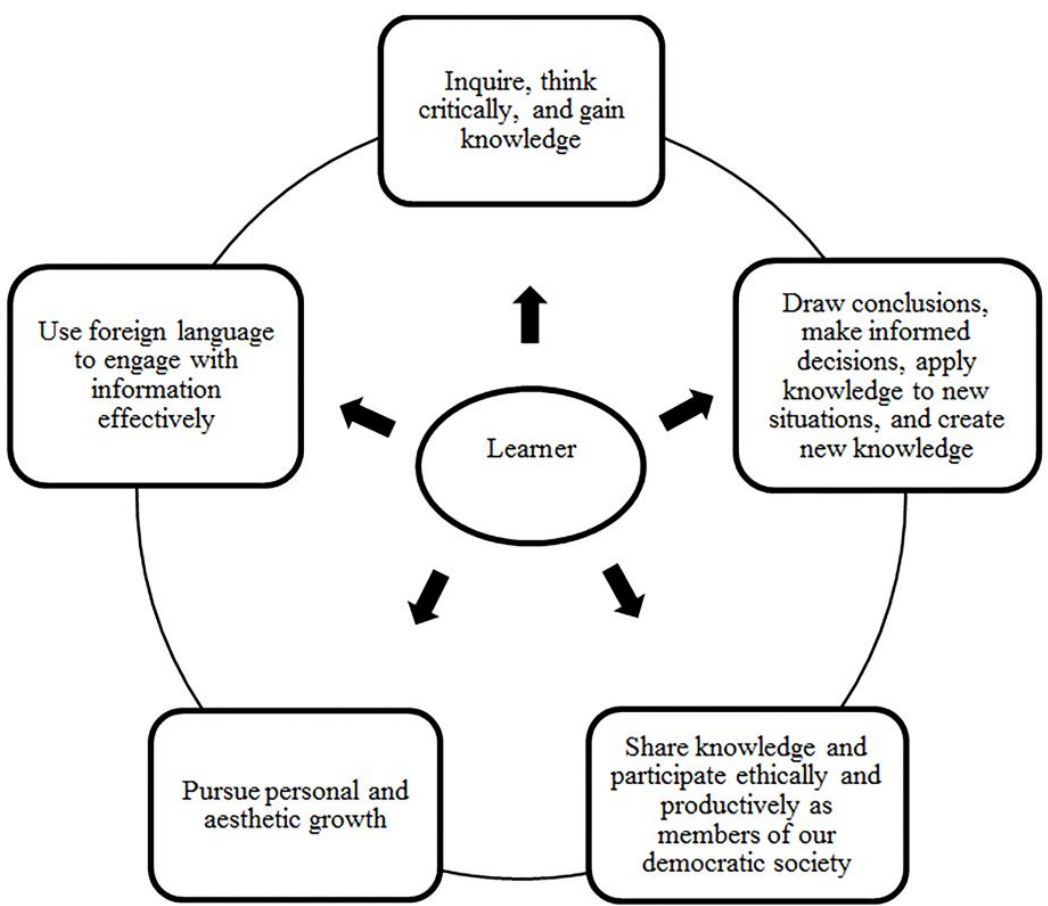

Figure 2. The expanded AASL model

Data collection was divided into two phases:

- Phase 1: The semi-structured interviews were undertaken to seek the students' responses (six students aged from 15-18, three from each school) regarding their experiences in IL learning and teaching.

- Phase 2: The professional interviews (two librarians, six teachers and two administrators) and document analysis were used to understand what and how instructions were delivered. This acted as a triangulation of findings generated through the student interviews. The review involved various documents at two levels: national and institutional level. At the national level, the Educational Development Strategy 2010-2020 and the Guidance on the Implementation of Secondary Education Tasks in the Academic Year 2014-2015, which were issued by MOET, were selected to analyse. At the institutional level, documents such as school and library reports, library statistics, teachers' resources and textbooks were interrogated. Documents were collected in two domains: public (MOET website and school websites) and private (schools, teachers and librarians).

The research was conducted at distance with limitations of time, budget and people. By using purposive sampling approach, the study collected qualitative data from two schools 
with the participation of 12 interviewees in total and an analysis of documents. The study employed in-depth interviews to gain a rich picture of the issues which, by its very nature, necessitates as smaller sample of participants. A cross-case analysis was conducted to explore the practice of IL teaching and learning between School B and C.

The researcher translated data collection instruments from English to Vietnamese as well as the responses of the participants and document texts from Vietnamese to English. The translation process might result in information loss and concepts might be understood differently between languages. The research made every effort to minimise this by conducting data analysis based on the original language (Vietnamese), using various English formulations to descript the meaning of the participants' responses and cooperating with a professional translator. The research also used a double translation process introduced by UNESCO (2013a).

\section{Findings and discussion}

\subsection{Lack of information literacy programmes}

The study found that IL still remained under-development at both national and institutional level. Both the students and the professionals supported this; "the school does not have any programme that can help me develop the ability to find, evaluate and use information" and "we do not have any specific instructions related to IL". The analysis of documents indicated that the study programme mainly focused on what students needed to achieve concerning knowledge, skills and attitudes. None of them showed evidence of the existence of IL instructions. Students could only receive simple instructions from their teachers regarding finding information when they conducted research projects. However, students only received guidance from their teachers when they made the request. One of the teachers said that: "I give students instructions regarding finding information in some cases, but not many". The library is expected to assist individuals in developing IL skills. Nevertheless, it appears that the two libraries still performed the function of a traditional library. They had not made any move to assist students in developing IL. The two librarians said that: "if students want to find a book and ask me, I will find it for them. That's all...This is a traditional library. We mainly deliver a loan and return service. We also have no instructions related to IL" and "my library does not give students IL instructions". This finding supports the view of many scholars, because they demonstrate that there is a lack of IL initiatives in educational institutions at all levels (Shenton et al., 2014). The lack of IL programmes is not only a noticeable issue in Vietnam but is also evident in many educational institutions 


\subsection{Challenges for the development of information literacy programmes}

5.2.1 Time pressure. It was clear from this investigation that time pressure was one of the main reasons leading to the nonexistence of IL programmes in the two schools. This issue could affect the implementation of the constructivist approach. This view is shared by Webber and Johnson (2006) who note that the busy subject curriculum can create challenges for teaching IL. Smith and Hepworth (2007, p. 12) suggested that school timetable should provide "lessons dedicated for research when students would have good access to resources and support", because time pressure was found dominated students in conducting project work. In this investigation, time pressure resulted from private class attendance and a strict learning timetable. The students said that: "In addition to the official classes, we have extra classes in Maths, Physics and Chemistry on Monday, Wednesday and Friday every week. I also have to attend special subject classes on Thursday afternoon. I spend too much time studying" and "I have to study in the school from the morning until afternoon, and I have private evening classes two days every week". Furthermore, teachers were allowed to organize private classes at home, as stated in school B's reports, "extra classes are organized for students...At present, $100 \%$ of the school's teachers are licensed and properly regulated to organize private classes". A busy learning schedule and private class attendance mean schools in general and students in particular have less time for alternative activities which can support the development of IL.

The constructivist approach requires students to search for meaning actively, and teachers undertake the role of a facilitator of learning. This actively creates favourable conditions for the development of critical inquiry. An overloaded schedule causes students to lose the need to develop IL to search for meaning in order to construct their new knowledge. According to library reports, the number of students visiting the library is 50 per day (4\%) and 20 per day (2\%) for School B and School C respectively. This rate is considered low. The participants believed that integrating IL into the formal curriculum could help them solve time pressure issues which were considered a challenge of the 
implementation of IL programmes in the schools. An administrator said that: "if we want to develop the new teaching and learning method, MOET should integrate IL into the study programme".

5.2.2 Teaching method. Evidence from this study shows that one reason for the neglect of students' IL teaching was as a result of a slow improvement in teaching methods. It appears that schools still gave priority to the traditional method. The tools for teaching and learning activities, such as textbooks, lesson plans and assessment scheme, have not been designed in compliance with the constructivist approach. This could result in a challenge for moving to the new teaching approach and developing IL. This finding reinforces research conducted by Nguyen and Williams (2016) who observed that a didactic teaching approach was still mainly used in Vietnam's education system. The spoon-feeding approach does not motivate students to engage with information outside of what has been taught by their teachers (Chang et al., 2012). The professionals said that: "at upper secondary education level, students are mainly tested on what they have been taught. This means they can get high scores by memorising what has been taught by teachers. IL is not helpful in this case, so we do not need to teach IL to students" and "teachers are substitutes for many things, even the library... What students learn is limited in the textbooks. Finding information outside of the textbook is not necessary". Furthermore, teachers are required to find information for their students instead of providing students with IL instructions to help them find information by themselves, as said by one of the teachers, "teachers take responsibility to find information for students. I think, to date, we still use the traditional teaching method whereby teachers provide knowledge to students".

The analysis of the textbooks found that the textbook design did not support students in approaching the constructivist model and developing IL. Lessons are divided into five sections: aims, main content, questions, summary and exercises. Questions and exercises mainly ask students to recall information from the main content. They sometimes provide questions that require students to explore further, for example: find more folk love songs. Nevertheless, they do not provide any instruction on how to do the tasks. It can be assumed that the textbooks still rely greatly on the didactic approach that does not promote lifelong learning in general and IL in particular.

Lesson plans and teacher textbooks are considered a main teaching resource. They were analysed to find instructions that could help students develop their IL. The study found that the didactic teaching approach was mainly used and there was an absence of IL instructions, for example: 
"Instructions for students to prepare for the next lesson:

- Memorise today's lesson

- Take a look at the exercises

- Read the next lesson: Vietnam's folklore" (Lesson plan - School C)

And

"As for teaching method, for this kind of lesson, teachers need to make more effort to find specific information for students" (Teacher textbook)

It can be seen that students were encouraged to memorise information rather than explore information outside the lessons. This may affect the development of students' IL, because outside materials and reading assignments allow students to practice their critical thinking and develop necessary information skills. As a result, the development of IL programmes has not received much attention from the schools and students. This is demonstrated by a lack of IL instructions, as discussed earlier.

Vietnam' schools are moving to a project-based learning approach, which is a mode of the constructivist approach. It is recommended that the project-based learning should be attached to the IL teaching model for Vietnam's upper secondary schools. The projectbased learning promotes independent learning (Smith and Hepworth, 2007). Independent learning and the free exploration of information enable learners to develop their critical thinking. Critical thinking skills are a requirement for the implementation of IL teaching (Walton and Hepworth, 2013). According to the students and professionals, "the school should require students to conduct projects. Let students raise their voice much more than teachers. This will help students develop their own knowledge" and "the new teaching and learning method that focuses on the project-based learning requires students to engage with information. Therefore, if you want to develop students' IL, you should pay more attention to that teaching and learning method".

Smith and Hepworth (2007) show that assessment methods have an influence on students' extrinsic motivation and that assessment is considered an essential part in a curriculum. This study found that schools still predominantly used the traditional approach to assess learning outcome which encourages memorising information. For example, the lesson plans require students to "recite the work "Summer Landscape" (Lesson plan School C) and "recite the poem "Thu Dieu" (Lesson plan - School B). The scoring table developed to assess students' tasks indicates that: "Students can present the assignment in different ways, but they have to ensure that they provide the following information and ideas" (Lesson plan - School B) and "Although giving scores based on the 
information/idea that has been taught is not encouraged, students still have to provide the full information/idea that is provided in the textbook" (Teacher textbook). The professionals confirmed that: "students are now experiencing exam stress and pressure, especially the traditional learning assessment method" and "if MOET changes the form of examinations, teachers will change the teaching method. Although they ask teachers to change the teaching method, they still assess students using the traditional learning assessment method". This assessment approach mainly concentrates on the learning potential inherent in the task. This does not encourage students to develop IL skills in order to improve their academic performance. It is recommended that project-based learning should be thoroughly implemented. Also, the learning outcome assessment method should be altered to make it suit a more constructivist approach.

\subsubsection{Human resources. It was found that issues surrounding human resources} significantly affected the development of IL programmes in the two schools and the implementation of the constructivist model. The study observed that librarians lacked professional qualifications. This result does not come as a surprise, because previous research indicated that Vietnam's school librarians did not have high quality professional capability (Vu et al., 2013). Lacking a teaching background may limit school librarians' contributions in the implementation of IL and teaching activities (Smith and Hepworth, 2007). One of the librarians said that: "the majority of school librarians do not have a professional qualification for librarians. Therefore, they do not have much understanding of IL". An analysis of the school and library reports found that each school had only one librarian who had a professional qualification as a school librarian. Accordingly, the development of IL programmes might face many challenges.

There was a lack of professional capability, IL capability and awareness of IL among teachers. Many teachers lacked ICT skills in general and more specifically were not familiar with internet use. They had a limited understanding and experience of the constructivist method, especially older generation teachers. This finding is consolidated by Nguyen and Hall (2017) who found that there was a lack of experience and understanding of the constructivist approach among Vietnam's teachers. Smith (2013) indicates that more work needs to be done to help teachers become IL implementers since many of them have not been prepared to deliver IL instructions to their students. There is a limited understanding of the IL concept among librarians and teachers (Smith, 2013). One of the students said that: "some teachers do not know how to find information on the internet. They do not even know whether the information is true". This was confirmed by one of the 
teachers, "younger teachers can use computers and email. However, for older teachers, some do not even know how to send an email. Therefore, never ask them to do anything like searching for information or to give such instructions to students". The school B report indicates that: "older teachers have limitations in their professional capability and they have no motivation to emulate and improve". Vietnamese teachers also lacked confidence of their IL skills and they therefore were not confidence in providing IL instructions to students, as said by one of the teachers, "I do not know how to instruct them to find information correctly". Additionally, Vietnamese teachers who took part in this research had not heard about the IL concept before participating in the study. Some of them could not provide a full explanation of the IL concept or understand the term in a different way. One of the librarians believed that: "IL is gathering information to satisfy individuals' needs", while the teachers said that: "IL is information that individuals identify from the world around them" and "IL is a noun that indicates a kind of knowledge". It was found that there were Vietnamese teachers who did not greatly appreciate the importance of IL to students, for example, "I do not think IL significantly affects students' learning. Students who take more effort to explore information can have a better understanding of issues than those who do not do that. However, it does not help students achieve good learning results". It is assumed that staff development is essential to enhance their understanding and competence of IL when implementing an IL programme (UNESCO, 2013a).

This study shows that administrators did not appreciate or understand the importance of the school library and IL to teaching and learning activities. This could be a challenge as developing information literate students is not only the responsibility of librarians or teachers, but also "all those who call themselves educators" (Bundy, 1999, p. 242). The librarians of both schools said that: "my current rector does not pay much attention to the library. He thinks that the library is simply a place to store books. It does not need library management software or database, etc." and "we have not provided any library introduction class in this academic year, because the board of rectors has not given us permission to organize such classes. In practice, they think that the library is not important, although they do not say that". Also, administrators had a limited understanding of the IL concept, those administrators who took part in this research only became aware of the term IL when they participated in the research, "I know the term 'information' or 'IT', but I have never heard about IL". It is suggested that administrative staff should take responsibility to manage issues surrounding planning, budget and staff development in order to ensure the success of IL initiatives. 
Poor collaboration between stakeholders, including administrators, teachers and librarians, made them unable to understand each other's activities and how other stakeholders could support for their own work. The study found that teachers and librarians did not collaborate with the other, either because teachers did not appreciate or understand the role of the library to their teaching. Research indicates that stakeholders, including librarians, faculty, administrators, academic staff and other information professionals within the school, need to work collaboratively in order to ensure the success of an IL programme (Pickard et al., 2011). Librarians cannot assess the effectiveness of IL instructions without the support from the faculty. On the contrary, teachers can be supported by librarians in identifying the presence of skills in the curriculum (Pickard et al., 2011). One of the librarians said that: "teachers do not think about how the library can support them". Furthermore, mutual support among teachers remained weak, as said by one of the teachers: "when I need help from other teachers, most of them refuse me. If I want to help my students. I will do it alone... The board of rectors also asks us to apply the project-based teaching method. However, they do not support us to do it". There is considerable evidence to suggest that lack of collaboration between stakeholders is highly significant in the context of this research. It is suggested that issues surrounding staff development and collaboration should be redressed in the IL teaching model for Vietnam's upper secondary schools.

5.2.4 Finance. The study found that a lack of financial support could result in the absence of IL instructions in the two schools and a slow changing from a didactic approach to a constructivist model. Specifically, the low salary made teachers and librarians have no motivation for alternative and teaching activities. According to Hamano (2008) and WB (2014), motivation is one of the key factors contributing to the success of the new teaching approach. This is demonstrated in the following statements: "some teachers persistently refused me when I asked them to do something in the school. They told me that they were too busy with their private classes and why was I forcing them to do such things when their salary was not high. Actually, a young teacher's salary is around 3 million Vietnamese Dong (VND) per month" 3" and "school librarians' salary is not high, so we do not want to deliver many activities on such an income. Based on the school library assessment criteria, they mainly focus on factors, such as the number of books, computers and book exhibition activities. They do not have criteria related to IL, so why should I have to do it". Educational

33 million VND equal around 100 British Pound or 130 US dollars. 
Development Strategy 2010-2020 indicates that "Regulations and policies are still inconsistent and have not created sufficient incentive to promote the potential of teaching staff'. The inconsistency of policies (including salary policy) might significantly affect teachers' contributions.

A lack of information sources, such as books and electronic information sources, that was a consequence of budget cuts might bring disadvantages in the implementation of IL instructions as well as teaching and learning activities. This finding is strengthened by research conducted by Dang (2012) and Vu et al. (2013) who demonstrated that there was a lack of financial support for Vietnam's school libraries. The librarians said that: "my school library receives around 10 million VND per year ${ }^{4}$. It is not enough to purchase new books for students" and "We would give students instructions related to IL if my school library was a digital library. We would have more reliable books and information sources to help students find information. At present, we do not need to teach them such skills because they can find books in the library easily". The analysis of documents found that the libraries did not have adequate financial support for activities. For example, each school library received financial support to acquire only 500 copies of books per year. Furthermore, the library statistics indicated that there was an absence of electronic information resources. The number of books in School B's library and School C's library was 11,683 and 2,312, respectively. They mainly acquired story books, textbooks, examination preparation books and professional books. As shown in the library reports, School B's library stopped using the library software because of budget cuts. In addition, restriction in the application of IT resulted in spending more time than usual to complete the library works. Similarly, School C's library showed that they stopped using the library software from the academic year 2014-2015 and delivering several services due to budget cuts. It is assumed that financial issues are macroscopic matters that the research cannot thoroughly settle. Issues related to information resources and funding are out of control of educational institutions and the researcher. It is recommended that IL instructions can start with free information sources and online search engines.

5.2.5 Students' awareness of information literacy. The study found that not all students were aware of the role of IL to their own learning. Thus, they did not have motivation to develop their IL. This could be a challenge of moving from a didactic approach to a constructivist model. Cognitive elements are pervasive in IL models. However, Bundy

${ }^{4} 10$ million VND equal around 330 British Pound or 450 US dollars. 
(1999) indicates that students' information awareness has not been well developed by the time they move in to college and university education. IL programmes need to concentrate on "fundamental task of shifting the youngsters' attitudes and changing their mindsets" (Pickard et al., 2014, p. 8). In this study, students were not willing to take part in activities that could develop their IL, as said by one of the librarians, "as from this year, my school library will no longer organize a library introduction class because students refuse to go to the class. Students who want to read books can borrow books in the library". One of the students states that: "I think that if you provide an IL course to students, they will give time for private classes rather than the IL course". The students did not highly value the importance of IL "IL is also unnecessary because it does not affect my life too much" and "I do not think that IL is important for us to pay much attention to it, because we have been taught by teachers what we should learn". Students did not highly appreciate the importance of IL to their learning achievement. They were still in favour of the teacher-centred study environment. It is suggested that factors related to students' awareness/cognition should be involved in the IL teaching model in Vietnam's upper secondary schools.

\subsubsection{Support from family. There is evidence that students' family could have} positive impact on the development of their children's IL and their learning. Students increasingly prefer to make use of people (e.g. family, friends and teachers) when searching for information (Smith and Hepworth, 2007). Evidence suggests that library anxiety and uncertainty may be one of the reasons for these young people making use of people when undertaking a search (Smith and Hepworth, 2007). One of the students said that: "my parents often introduce good books and websites to me to help me obtain useful information". There is evidence that parents' IT knowledge has a positive influence on students (Duffy et al., 2010). On the contrary, Chang et al. (2012) revealed that students' ethics scores were negatively affected by their father's highest educational qualification. Research indicates that there is an impact of students' family/parents to their IL development. It could be either a negative or positive impact. In the context of this study, support from family positively affected the development of students' IL.

Parents not only affects the development of IL but also influence changing Vietnam's education culture. One of the administrators said that "not all families are interested in the school's educational policies. Some families even do not allow their children to allow their children to use the computer even though they have it". This view was reinforced by one of the teachers, as follows "If parents can control their children, students will study very well and make an effort to search for more information". They believed that family support could 
affect students' learning in general and IL in particular. Students who received more attention from their family would be motivated to engage with information and develop the necessary skills to support their learning. As mentioned in the context of the study, the desire and value of family has created a lot of pressure for students. Lack of understanding of the new learning and teaching approach and lack of support from family could prevent students from developing new ways of learning. From what has been discussed above, an idea of involving parents in an IL intervention for Vietnamese upper secondary students has emerged.

\section{An information literacy teaching model for Vietnam's upper secondary schools}

Here the study introduces an IL teaching model which offers a framework to Vietnam's schools to design, develop and deliver IL programmes (Figure 3). The model addresses issues surrounding factors affecting the development of IL teaching, as discussed earlier. The expanded AASL model is also included.

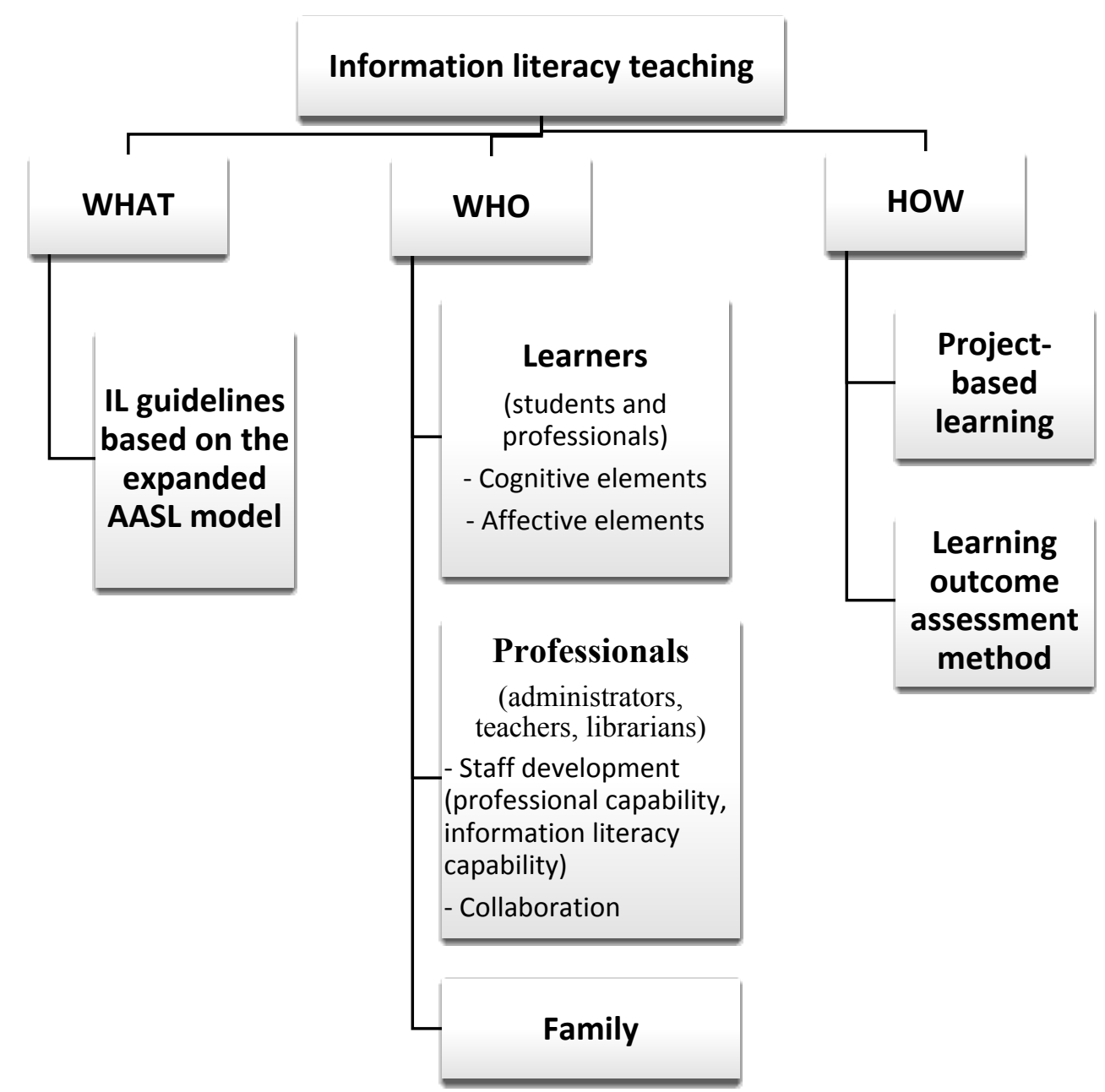


Figure 3. Information literacy teaching model for Vietnam's upper secondary schools

The model begins with "WHAT", the school takes the initial step of identifying what needs to be taught to students regarding IL. It includes the expanded AASL model proposed. Its standards and indicators can be used as a guideline to design IL instructions.

This is followed by, "WHO”, which primarily concentrates on issues surrounding stakeholders, such as professionals, students and their family. As discussed earlier, cognitive (awareness) and affective (motivation) elements directly affect the development of IL programmes. Specifically, the study reveals that students had a lack of awareness of IL and a lack of motivation to develop their IL. Cognitive and affective elements also have a great effect on delivering IL instructions among school administrators, teachers and librarians. Thus, the two components are recommended as an essential part of the model.

It is suggested that staff development and collaboration should receive attention of schools in order to ensure the success of IL programmes. Staff development is required to improve professionals' IL teaching capability. The collaboration between teachers, librarians and administrators is also emphasised to ensure the long-term development of IL initiatives. Furthermore, the support from family can motivate students to develop their IL more effectively.

The third part of the model, "HOW", indicates how to implement an IL programme. Students' IL and IL initiatives cannot be developed effectively if the didactic approach in teaching is still used in the education system. The model encourages the use of the projectbased learning approach which is being implemented in the education system in Vietnam. This approach should be followed by an appropriate learning outcome assessment strategy. Thoroughly employing the project-based learning approach and an appropriate learning assessment strategy may help schools solve problems related to time pressure.

\section{Conclusion}

This research provides an insight into the practice of IL teaching and learning in Vietnam's upper secondary schools. The development of IL programmes in Vietnam's high schools faces many challenges that can be encountered across educational institutions of both developing and developed countries, such as lack of IL programmes, teaching method, resources, collaboration, teaching capability and cognitive readiness of professionals, time pressure, students' awareness of IL and support from family. Nevertheless, contextual issues surrounding the absence of IL programmes, teaching method, lacking resources and 


\section{References}

AASL (2007), Standards for the 21st-Century Learner, American Library Association, Chicago.

Accardi, M., Drabinski, E. and Kumbier, A. (2014), Critical library instruction: theories and methods, Library Juice Press, Duluth.

Bundy, A. (1999), "Information literacy: the 21st-century educational smartcard", Australian Academic \& Research Libraries, Vol. 30 No. 4, pp. 233-250.

Central Committee of the Communist Party of Vietnam (2013), Resolution of the 11th Congress of the Communist Party No. 29-NQ/TW on fundamentally and comprehensively renovating education and training, Central Committee of the Communist Party of Vietnam, Hanoi, available at: http://thuvienphapluat.vn/vanban/Thuong-mai/Nghi-quyet-29-NQ-TW-nam-2013-doi-moi-can-ban-toan-diengiao-duc-dao-tao-hoi-nhap-quoc-te-212441.aspx (accessed 05 December 2018).

Chang, Y., Zhang, X., Mokhtar, I., Foo, S., Majid, S., Luyt, B. and Theng, Y. (2012), "Assessing students' information literacy skills in two secondary schools in Singapore", Journal of Information Literacy, Vol. 6 No. 2, pp. 19-34.

Dang, A. (2011), Private tutoring in Vietnam: a review of current issues and its major correlates, World Bank, Washington DC.

Dang, U. (2012), "Country update: Vietnam (April 2011-April 2012)", paper presented at the 20th Conference of Directors of National Libraries of Asia and Oceania (CDNL-AO): National Heritage: Preservation and Dissemination, 28 May, Kuta, Bali-Indonesia, available at: 
http://www.ndl.go.jp/en/cdnlao/meetings/pdf/CR2012_Vietnam.pdf (accessed 20 March 2018).

Dorner, D. (2017), "Chapter E. Region: Asia/Oceania", in ACRL (Ed.), Global Perspectives on Information Literacy: Fostering a Dialogue for International Understanding, Association of College and Research Libraries, Chicago, pp. 47-59.

Dorner, D. and Gorman, G. (2006), "Information literacy education in Asian developing countries: cultural factors affecting curriculum development and programme delivery", IFLA Journal, Vol. 32 No. 4, pp. 281-293.

Duffy, A., Liying, T. and Ong, L. (2010), "Singapore teens' perceived ownership of online sources and credibility", First Monday, Vol. 15 No. 4, available at: http://firstmonday.org/ojs/index.php/fm/article/view/2197/2484 (accessed 10 March 2018).

Hamano, T. (2008), "Educational reform and teacher education in Vietnam", Journal of Education for Teaching, Vol. 34 No. 4, pp. 397-410.

Layder, D. (1993), New strategies in social research: an introduction and guide, Polity Press, Cambridge.

Limberg, L., Sundin, O. and Talja, S. (2012), "Three theoretical perspectives on information literacy", Human It, Vol. 11 No. 2, pp. 93-130.

Lloyd, A. (2012), "Information literacy as a socially enacted practice; Sensitising themes for an emerging perspective of people-in-practice", Journal of Documentation, Vol. 68 No. 6, pp. 772-783.

London, J. (2011), Education in Vietnam, Institute of Southeast Asian Studies ISEAS, Singapore.

Mayes, T. and de Freitas, S. (2013), “Technology-enhanced learning: the role of theory”, in Beetham, H. and Sharpe, R. (Eds.), Rethinking Pedagogy for A Digital Age:

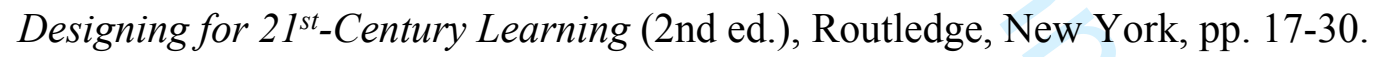

MOET (2014), Education for All 2015 National Review Report: Vietnam, available at: https://unesdoc.unesco.org/ark:/48223/pf0000232770 (accessed 05 December 2018). 
Nguyen, N. and Williams, P. (2016), "An ICT supported sociocultural approach to improve the teaching of physics", Asia-Pacific Science Education, Vol. 2 No. 1, pp. 1-21.

Nguyen, T. M. H. and Hall, C. (2017), "Changing views of teachers and teaching in Vietnam", Teaching Education, Vol. 28 No. 3, pp. 244-256.

Nguyen, T. Q. T. (2015), "The influence of traditional beliefs on Vietnamese college lecturers' perceptions of face", Journal of Education for Teaching, Vol. 41 No. 2, pp. 203-214.

Nguyen, V. (2013), Orienting to pedagogical innovation: a case study of Vietnamese teachers' beliefs and practices regarding task-based language teaching, thesis, Hanilton, New Zealand, University of Waikato, available at: http://researchcommons.waikato.ac.nz/handle/10289/7433 (accessed 9 March 2018).

Norgaard, R., Arp, L. and Woodard, B. S. (2003), "Writing information literacy contributions to a concept", Reference and User Services Quarterly, Vol. 43 No. 2, pp. 124-130.

Peeraer, J. and Van Petegem, P. (2011), "ICT in teacher education in an emerging developing country: Vietnam's baseline situation at the start of 'The Year of ICT'", Computers \& Education, Vol. 56 No. 4, pp. 974-982.

Pickard, A., Gannon-Leary, P. and Coventry, L. (2011), "The onus on us? Instilling trust in our users", Library and Information Research Journal, Vol. 35 No. 111, pp. 87104.

Pickard, A., Shenton, A. and Johnson, A. (2014), "Young people and the evaluation of information on the World Wide Web: principles, practice and beliefs", Journal of Librarianship and Information Science, Vol. 46 No. 1, pp. 3-20.

Prime Minister (2011), Decision No. 1216/QĐ-TTg on approving the project "Developing Human Resources in Vietnam 2011-2020", Prime Minister of Vietnam, Hanoi, available at: http://thuvienphapluat.vn/van-ban/Lao-dong-Tien-luong/Quyet-dinh1216-QD-TTg-phe-duyet-Quy-hoach-phat-trien-nhan-luc-Viet-Nam-126974.aspx (accessed 05 December 2018). 
Shenton, A., Pickard, A. and Johnson, A. (2014), "Information evaluation and the individual's cognitive state: some insights from a study of British teenaged users", IFLA Journal, Vol. 40 No. 4, pp. 307-316.

Smith, J. (2013), "Secondary teachers and information literacy (IL): teacher understanding and perceptions of IL in the classroom", Library and Information Science Research, Vol. 35 No. 3, pp. 216-222.

Smith, M. and Hepworth, M. (2007), "An investigation of factors that may demotivate secondary school students undertaking project work: Implications for learning information literacy", Journal of Librarianship and Information Science, Vol. 39 No. 1, pp. 3-15.

UNESCO (2013a), Global Media and Information Literacy Assessment Framework: Country readiness and competencies, UNESCO, Paris.

UNESCO (2013b), ICT in education policy, infrastructure and ODA status in selected ASEAN countries, Asia and Pacific Regional Bureau for Education, Bangkok.

UNESCO (2015), Education for All 2000-2015: achievements and challenges; EFA global monitoring report 2015, available at: https://en.unesco.org/gemreport/report/2015/education-all-2000-2015-achievements-and-challenges (accessed 05 December 2018).

Vu, N., Pham, R. and Le, H. (2013), "Investment to Vietnam's libraries: real situations and solutions", Journal of Information and Documents, Vol. 4, pp. 3-12.

Walton, G. and Cleland, J. (2013), "Becoming an independent learner", in Secker, J. and Coonan, E. (Eds.), Rethinking Information Literacy: A Practical Framework for Supporting Learning, Facet, London, pp. 13-26.

Walton, G. and Hepworth, M. (2013), "Using assignment data to analyse a blended information literacy intervention: a quantitative approach", Journal of Librarianship and Information Science, Vol. 45 No. 1, pp. 53-63.

Webber, S. and Johnson, B. (2006), "Working towards the informayion literate university", in Walton, G. and Pope, A. (Eds.), Information Literacy: Recognising the Need, Chandos Publishing, Oxford, pp. 47-58.

World Bank (2011), Vietnam: high quality education for all by 2020, available at: http://documents.worldbank.org/curated/en/416151468320084130/Overviewpolicy-report (accessed 05 December 2018). 
World Bank (2014), Skilling up Vietnam: preparing the workforce for a modern market economy - Vietnam Development Report 2014, available at: http://documents.worldbank.org/curated/en/283651468321297015/Skilling-upVietnam-preparing-the-workforce-for-a-modern-market-economy (accessed 05 December 2018). 


\title{
An information literacy teaching model for Vietnam's schools
}

\begin{abstract}
Purpose - This study aims to identify the ways in which information literacy (IL) inpractice initiatives are framed for Vietnam's upper secondary students and to suggest an appropriate IL teaching model for schools in the country.
\end{abstract}

Design/methodology/approach - The research employed a qualitative multiple case study approach, including two phases of data collection. The first phase gathered data from semistructured student interviews. The second phase included semi-structured professional interviews and an analysis of documents.

Findings - The research found that time pressure, teaching method, resource issues, students' awareness of IL and support from family are challenges for the development of IL programmes. These factors contribute to the development of an IL teaching model for Vietnam's upper secondary schools.

Research limitations/implications - The focus of this study was limited to two schools in order to gain the depth of data needed to provide a holistic picture of the practice of IL teaching in Vietnam's upper secondary schools.

Practical implications - This study could provide some guidance to the Ministry of Education and Training in the development of educational policies and initiatives through identifying the possible contributions of IL to Vietnam's education system.

Originality/value - The study provides an understanding of the development of IL in the education system in transition, from a didactic to a constructivist approach.

Keywords Information literacy, High school, Vietnam, Pedagogy

Paper type Research paper

\section{Introduction}

In the educational environment, schools are striving to prepare students to meet the changes of the information environment. Despite the important role of information literacy (IL) being widely acknowledged, there is still a lack of IL programmes implemented in educational institutions (Shenton et al., 2014). This paper reports on the findings of a qualitative research which aims to identify the ways in which IL in-practice initiatives are framed for Vietnam's upper secondary students and to suggest an appropriate IL teaching model for schools in the country. 


\section{Context of the study}

The blending of three ideologies, Confucianism, Taoism and Buddhism, has contributed to the development of Vietnam's society and culture. They put the emphasis on the hierarchy of superior-inferior relationships, human suffering, and the relationship between humans and the cosmos. This has created the notable characteristics of passivity, compliance, submissiveness, acceptance of fate and maintenance of the status quo in Asian countries' culture and that of Vietnam. This creates the ideal environment for the ingrained acceptance of passive learning and the teacher-centred teaching model in Vietnam (Nguyen, 2013).

The Vietnamese believe that learning is the only path for advancement (World Bank (WB), 2011). Therefore, Vietnamese families invest more in their children's education. Additionally, the value of family is highly appreciated. This has created a lot of pressure for students. Students have to study as hard as they can to achieve good results in examinations.

Since 1986, Vietnam conducted a number of economic and political reforms called "Đổi mới" (Renovation) which allowed the Vietnamese economy to integrate into the globalised world (WB, 2014). This results in a wave of foreign investment into Vietnam. The transition sets out a requirement that workers need to be equipped with the right skills (WB, 2014). The Economic and Social Development Strategy and Human Resource Development Project 2011-2020 indicates that developing human resources to fulfil the requirements of international integration is Vietnam's focus (Prime Minister, 2011). Furthermore, in order to achieve the educational objective "Developing creativity and selflearning; and encouraging lifelong learning" (Central Committee of the Communist Party of Vietnam, 2013, p. 4), therefore for this to be realised, there is a need to employ a constructivist approach as it promotes a learner-centred learning environment, learners' independent thinking and active learning (Mayes \& de Freitas, 2013). In recent years, there have been attempts made to replace the traditional delivery mode of transmission by a constructivist approach. However, studies point out that a didactic approach remains prevalent in the education system (Nguyen and Williams, 2016). London (2011) argues that there is a significant gap between educational policies and practice. This problem could result from lacking experience and understanding to the 'Western theories' among teachers (Nguyen and Hall, 2017), their persistent beliefs on 'face saving' (Nguyen, 2015), unequal understanding and insufficient attention from local areas for education development strategy, and insufficient human resources at all levels (Ministry of Education and Training 
(MOET), 2014). According to Hamano (2008), teacher education is necessary in the innovation process.

In Vietnam, over the past decade, many schools have applied the full day schooling policy. They organize extra classes ${ }^{1}$ for the remaining half of the day under the agreement of the students' families in order to provide additional knowledge in main subjects. At the same time, many students attend private classes ${ }^{2}$ in the afternoon and evening. Dang (2011) found that $32 \%$ of primary school students attended private classes, while the percentage of lower and upper secondary school students was $46 \%$ and $63 \%$, respectively. There are several reasons for the recent spread of private classes, one being social competition. Another reason is teachers organize private classes to increase their income. Students attend those classes with the aim of seeking good grades in the formal classes and, as a result, private class attendance causes a range of problems, such as lack of time for alternative activities, undue and unofficial payment pressure to avoid failing the exam, a decrease in teachers' motivation during the formal teaching hours and educational inequality (WB, 2014).

The quality of Vietnam's education system is significantly influenced by the international movement to promote 'Education for All' (EFA) supported by the United Nations Educational, Scientific and Cultural Organization (UNESCO) (2015). Vietnam established the National Action Plan for EFA (2003-2015) which concentrates on early childhood care and education, basic education (primary and lower-secondary education) and non-formal education (continuing education) (MOET, 2014).

It is assumed that international organizations play an important role in making positive changes to the Vietnamese education system in terms of infrastructure, curriculum development and teacher education. This could be found in educational projects such as "Targeted Budget Support for EFA" supported by WB, the United Kingdom Department for International Development (DFID), Canadian International Development Agency, the European Union, and the governments of Belgium, Spain and New Zealand; "School Education Quality Assurance project" supported by WB and DFID; "New School Model" funded by the Global Partnership for Education, WB and UNESCO; "Primary Teacher Development" supported by WB; "Project for Improving Pre- and In-service Training of Primary and Lower Secondary Teachers in the Northern Highlands of Vietnam" funded by Belgian Technical Corporation; and "In-service Teacher Improvement Programme"

\footnotetext{
${ }^{1}$ By extra classes, this paper means classes which are organized by schools after official classes.

${ }^{2}$ By private classes, this paper means classes which are individually organized by teachers.
} 


\section{Information literacy and its contextual and cultural nature}

IL can be interpreted and defined from different perspectives. According to Walton and Cleland (2013), the development of IL capability ensues from a broader social setting and that IL comprises three spheres, finding, evaluating and using information, and each scope activates its own set of behavioural, cognitive, metacognitive and affective elements. Lloyd (2012, p. 772), by examining how people connect with the information landscape that forms their settings or practices, sees IL "as a socially enacted practice". The sociocultural perspective of IL views "how people's use of information cannot be 
meaningfully separated from the tools that are an integral part of social practices" (Limberg et al., 2012, p. 95). Instead of identifying IL as a set of skills, this point of view recognises IL in its relationship with the information setting, which has a strong influence on how people understand information.

Information is "connected to larger cultural, historical, social and political systems" (Norgaard et al., 2003, p. 126). Meanwhile, literacy is also a culturally situated phenomenon (Accardi et al., 2014). By bringing together 'information' and 'literacy', IL becomes a cultural concept. The cultural nature of IL has been explored in a number of recent studies because the development of IL in non-Western countries has received the attention of researchers. Based on studies on IL education in Asian countries, Dorner indicates that "the diversity in populations, politics, cultures, and levels of economic prosperity is immense and greatly affects IL and IL education across the region" (Dorner, 2017 , p. 47). It is suggested that the local context in general and local cultural norms in particular needs to be considered in order to promote the development of IL programmes (Dorner and Gorman, 2006).

An IL definition in developing countries was introduced by Dorner and Gorman (2006, p. 284) who define IL as:

The ability of individuals or groups to be aware of why, how and by whom information is created, communicated and controlled, and how it contributes to the construction of knowledge; to understand when information can be used to improve their daily living or to contribute to the resolution of needs related to specific situations, such as at work or school; to know how to locate information and to critique its relevance and appropriateness to their context; to understand how to integrate relevant and appropriate information with what they already know to new construct knowledge that increases their capacity to improve their daily living or to resolve needs related to specific situations that have arisen.

This definition emphasises the contextual and cultural nature of IL that has led to differences in IL education between Western and non-Western countries.

\section{Methodology}

This qualitative research focused on two of Vietnam's upper secondary schools, in which each school was treated as a single case. The research brought the context of each case/school at both macro and micro environment level together based on Layder's (1993) approach (Figure 1). 
"Insert Figure 1. The context of two schools at both macro and micro environment here"

The study chose the Standards for the $21^{\text {st }}$-Century Learner (American Association of School Librarians (AASL), 2007) as its theoretical framework because the focus of the model is on the K-12 education environment and students' learning. The original AASL model takes into account some of the criticisms made against other earlier models. In 2013, UNESCO introduced a Global Media and Information Literacy (MIL) Assessment Framework, but it mainly concentrates on teachers' MIL competencies in service and in training rather than students (UNESCO, 2013a). Therefore, the AASL provides a more robust model than UNESCO's at present. The expanded version of the Standards for the $21^{\text {st }}$-Century Learner, as illustrated in Figure 2 (see XXXXXXX for further details), was used to examine the practice of IL teaching and learning in the schools.

"Insert Figure 2. The expanded AASL model here"

Data collection was divided into two phases:

- Phase 1: The semi-structured interviews were undertaken to seek the students' responses (six students aged from 15-18, three from each school) regarding their experiences in IL learning and teaching.

- Phase 2: The professional interviews (two librarians, six teachers and two administrators) and document analysis were used to understand what and how instructions were delivered. This acted as a triangulation of findings generated through the student interviews. The review involved various documents at two levels: national and institutional level. At the national level, the Educational Development Strategy 2010-2020 and the Guidance on the Implementation of Secondary Education Tasks in the Academic Year 2014-2015, which were issued by MOET, were selected to analyse. At the institutional level, documents such as school and library reports, library statistics, teachers' resources and textbooks were interrogated. Documents were collected in two domains: public (MOET website and school websites) and private (schools, teachers and librarians).

The research was conducted at distance with limitations of time, budget and people. By using purposive sampling approach, the study collected qualitative data from two schools with the participation of 12 interviewees in total and an analysis of documents. The study employed in-depth interviews to gain a rich picture of the issues which, by its very nature, 
necessitates as smaller sample of participants. A cross-case analysis was conducted to explore the practice of IL teaching and learning between School B and C.

The researcher translated data collection instruments from English to Vietnamese as well as the responses of the participants and document texts from Vietnamese to English. The translation process might result in information loss and concepts might be understood differently between languages. The research made every effort to minimise this by conducting data analysis based on the original language (Vietnamese), using various English formulations to descript the meaning of the participants' responses and cooperating with a professional translator. The research also used a double translation process introduced by UNESCO (2013a).

\section{Findings and discussion}

\subsection{Lack of information literacy programmes}

The study found that IL still remained under-development at both national and institutional level. Both the students and the professionals supported this; "the school does not have any programme that can help me develop the ability to find, evaluate and use information" and "we do not have any specific instructions related to IL". The analysis of documents indicated that the study programme mainly focused on what students needed to achieve concerning knowledge, skills and attitudes. None of them showed evidence of the existence of IL instructions. Students could only receive simple instructions from their teachers regarding finding information when they conducted research projects. However, students only received guidance from their teachers when they made the request. One of the teachers said that: "I give students instructions regarding finding information in some cases, but not many". The library is expected to assist individuals in developing IL skills. Nevertheless, it appears that the two libraries still performed the function of a traditional library. They had not made any move to assist students in developing IL. The two librarians said that: "if students want to find a book and ask me, I will find it for them. That's all...This is a traditional library. We mainly deliver a loan and return service. We also have no instructions related to IL" and "my library does not give students IL instructions". This finding supports the view of many scholars, because they demonstrate that there is a lack of IL initiatives in educational institutions at all levels (Shenton et al., 2014). The lack of IL programmes is not only a noticeable issue in Vietnam but is also evident in many educational institutions around the world. The absence of IL instructions at high school education level may bring disadvantages for students when they enter higher education. It is suggested that the 


\subsection{Challenges for the development of information literacy programmes}

5.2.1 Time pressure. It was clear from this investigation that time pressure was one of the main reasons leading to the nonexistence of IL programmes in the two schools. This issue could affect the implementation of the constructivist approach. This view is shared by Webber and Johnson (2006) who note that the busy subject curriculum can create challenges for teaching IL. Smith and Hepworth (2007, p. 12) suggested that school timetable should provide "lessons dedicated for research when students would have good access to resources and support", because time pressure was found dominated students in conducting project work. In this investigation, time pressure resulted from private class attendance and a strict learning timetable. The students said that: "In addition to the official classes, we have extra classes in Maths, Physics and Chemistry on Monday, Wednesday and Friday every week. I also have to attend special subject classes on Thursday afternoon. I spend too much time studying" and "I have to study in the school from the morning until afternoon, and I have private evening classes two days every week". Furthermore, teachers were allowed to organize private classes at home, as stated in school B's reports, "extra classes are organized for students...At present, $100 \%$ of the school's teachers are licensed and properly regulated to organize private classes". A busy learning schedule and private class attendance mean schools in general and students in particular have less time for alternative activities which can support the development of IL.

The constructivist approach requires students to search for meaning actively, and teachers undertake the role of a facilitator of learning. This actively creates favourable conditions for the development of critical inquiry. An overloaded schedule causes students to lose the need to develop IL to search for meaning in order to construct their new knowledge. According to library reports, the number of students visiting the library is 50 per day (4\%) and 20 per day (2\%) for School B and School C respectively. This rate is considered low. The participants believed that integrating IL into the formal curriculum could help them solve time pressure issues which were considered a challenge of the implementation of IL programmes in the schools. An administrator said that: "if we want to 
develop the new teaching and learning method, MOET should integrate IL into the study programme".

5.2.2 Teaching method. Evidence from this study shows that one reason for the neglect of students' IL teaching was as a result of a slow improvement in teaching methods. It appears that schools still gave priority to the traditional method. The tools for teaching and learning activities, such as textbooks, lesson plans and assessment scheme, have not been designed in compliance with the constructivist approach. This could result in a challenge for moving to the new teaching approach and developing IL. This finding reinforces research conducted by Nguyen and Williams (2016) who observed that a didactic teaching approach was still mainly used in Vietnam's education system. The spoon-feeding approach does not motivate students to engage with information outside of what has been taught by their teachers (Chang et al., 2012). The professionals said that: "at upper secondary education level, students are mainly tested on what they have been taught. This means they can get high scores by memorising what has been taught by teachers. IL is not helpful in this case, so we do not need to teach IL to students" and "teachers are substitutes for many things, even the library... What students learn is limited in the textbooks. Finding information outside of the textbook is not necessary". Furthermore, teachers are required to find information for their students instead of providing students with IL instructions to help them find information by themselves, as said by one of the teachers, "teachers take responsibility to find information for students. I think, to date, we still use the traditional teaching method whereby teachers provide knowledge to students".

The analysis of the textbooks found that the textbook design did not support students in approaching the constructivist model and developing IL. Lessons are divided into five sections: aims, main content, questions, summary and exercises. Questions and exercises mainly ask students to recall information from the main content. They sometimes provide questions that require students to explore further, for example: find more folk love songs. Nevertheless, they do not provide any instruction on how to do the tasks. It can be assumed that the textbooks still rely greatly on the didactic approach that does not promote lifelong learning in general and IL in particular.

Lesson plans and teacher textbooks are considered a main teaching resource. They were analysed to find instructions that could help students develop their IL. The study found that the didactic teaching approach was mainly used and there was an absence of IL instructions, for example:

"Instructions for students to prepare for the next lesson: 
- Memorise today's lesson

- Take a look at the exercises

- Read the next lesson: Vietnam's folklore" (Lesson plan - School C)

And

"As for teaching method, for this kind of lesson, teachers need to make more effort to find specific information for students" (Teacher textbook)

It can be seen that students were encouraged to memorise information rather than explore information outside the lessons. This may affect the development of students' IL, because outside materials and reading assignments allow students to practice their critical thinking and develop necessary information skills. As a result, the development of IL programmes has not received much attention from the schools and students. This is demonstrated by a lack of IL instructions, as discussed earlier.

Vietnam' schools are moving to a project-based learning approach, which is a mode of the constructivist approach. It is recommended that the project-based learning should be attached to the IL teaching model for Vietnam's upper secondary schools. The projectbased learning promotes independent learning (Smith and Hepworth, 2007). Independent learning and the free exploration of information enable learners to develop their critical thinking. Critical thinking skills are a requirement for the implementation of IL teaching (Walton and Hepworth, 2013). According to the students and professionals, "the school should require students to conduct projects. Let students raise their voice much more than teachers. This will help students develop their own knowledge" and "the new teaching and learning method that focuses on the project-based learning requires students to engage with information. Therefore, if you want to develop students' IL, you should pay more attention to that teaching and learning method".

Smith and Hepworth (2007) show that assessment methods have an influence on students' extrinsic motivation and that assessment is considered an essential part in a curriculum. This study found that schools still predominantly used the traditional approach to assess learning outcome which encourages memorising information. For example, the lesson plans require students to "recite the work "Summer Landscape" (Lesson plan School C) and "recite the poem "Thu Dieu" (Lesson plan - School B). The scoring table developed to assess students' tasks indicates that: "Students can present the assignment in different ways, but they have to ensure that they provide the following information and ideas" (Lesson plan - School B) and "Although giving scores based on the information/idea that has been taught is not encouraged, students still have to provide the 
full information/idea that is provided in the textbook" (Teacher textbook). The professionals confirmed that: "students are now experiencing exam stress and pressure, especially the traditional learning assessment method" and "if MOET changes the form of examinations, teachers will change the teaching method. Although they ask teachers to change the teaching method, they still assess students using the traditional learning assessment method". This assessment approach mainly concentrates on the learning potential inherent in the task. This does not encourage students to develop IL skills in order to improve their academic performance. It is recommended that project-based learning should be thoroughly implemented. Also, the learning outcome assessment method should be altered to make it suit a more constructivist approach.

\subsubsection{Human resources. It was found that issues surrounding human resources} significantly affected the development of IL programmes in the two schools and the implementation of the constructivist model. The study observed that librarians lacked professional qualifications. This result does not come as a surprise, because previous research indicated that Vietnam's school librarians did not have high quality professional capability (Vu et al., 2013). Lacking a teaching background may limit school librarians' contributions in the implementation of IL and teaching activities (Smith and Hepworth, 2007). One of the librarians said that: "the majority of school librarians do not have a professional qualification for librarians. Therefore, they do not have much understanding of IL". An analysis of the school and library reports found that each school had only one librarian who had a professional qualification as a school librarian. Accordingly, the development of IL programmes might face many challenges.

There was a lack of professional capability, IL capability and awareness of IL among teachers. Many teachers lacked ICT skills in general and more specifically were not familiar with internet use. They had a limited understanding and experience of the constructivist method, especially older generation teachers. This finding is consolidated by Nguyen and Hall (2017) who found that there was a lack of experience and understanding of the constructivist approach among Vietnam's teachers. Smith (2013) indicates that more work needs to be done to help teachers become IL implementers since many of them have not been prepared to deliver IL instructions to their students. There is a limited understanding of the IL concept among librarians and teachers (Smith, 2013). One of the students said that: "some teachers do not know how to find information on the internet. They do not even know whether the information is true". This was confirmed by one of the teachers, "younger teachers can use computers and email. However, for older teachers, some 
do not even know how to send an email. Therefore, never ask them to do anything like searching for information or to give such instructions to students". The school B report indicates that: "older teachers have limitations in their professional capability and they have no motivation to emulate and improve". Vietnamese teachers also lacked confidence of their IL skills and they therefore were not confidence in providing IL instructions to students, as said by one of the teachers, "I do not know how to instruct them to find information correctly". Additionally, Vietnamese teachers who took part in this research had not heard about the IL concept before participating in the study. Some of them could not provide a full explanation of the IL concept or understand the term in a different way. One of the librarians believed that: "IL is gathering information to satisfy individuals' needs", while the teachers said that: "IL is information that individuals identify from the world around them" and "IL is a noun that indicates a kind of knowledge". It was found that there were Vietnamese teachers who did not greatly appreciate the importance of IL to students, for example, "I do not think IL significantly affects students' learning. Students who take more effort to explore information can have a better understanding of issues than those who do not do that. However, it does not help students achieve good learning results". It is assumed that staff development is essential to enhance their understanding and competence of IL when implementing an IL programme (UNESCO, 2013a).

This study shows that administrators did not appreciate or understand the importance of the school library and IL to teaching and learning activities. This could be a challenge as developing information literate students is not only the responsibility of librarians or teachers, but also "all those who call themselves educators" (Bundy, 1999, p. 242). The librarians of both schools said that: "my current rector does not pay much attention to the library. He thinks that the library is simply a place to store books. It does not need library management software or database, etc." and "we have not provided any library introduction class in this academic year, because the board of rectors has not given us permission to organize such classes. In practice, they think that the library is not important, although they do not say that". Also, administrators had a limited understanding of the IL concept, those administrators who took part in this research only became aware of the term IL when they participated in the research, "I know the term 'information' or 'IT', but I have never heard about IL". It is suggested that administrative staff should take responsibility to manage issues surrounding planning, budget and staff development in order to ensure the success of IL initiatives. 
Poor collaboration between stakeholders, including administrators, teachers and librarians, made them unable to understand each other's activities and how other stakeholders could support for their own work. The study found that teachers and librarians did not collaborate with the other, either because teachers did not appreciate or understand the role of the library to their teaching. Research indicates that stakeholders, including librarians, faculty, administrators, academic staff and other information professionals within the school, need to work collaboratively in order to ensure the success of an IL programme (Pickard et al., 2011). Librarians cannot assess the effectiveness of IL instructions without the support from the faculty. On the contrary, teachers can be supported by librarians in identifying the presence of skills in the curriculum (Pickard et al., 2011). One of the librarians said that: "teachers do not think about how the library can support them". Furthermore, mutual support among teachers remained weak, as said by one of the teachers: "when I need help from other teachers, most of them refuse me. If I want to help my students. I will do it alone... The board of rectors also asks us to apply the project-based teaching method. However, they do not support us to do it". There is considerable evidence to suggest that lack of collaboration between stakeholders is highly significant in the context of this research. It is suggested that issues surrounding staff development and collaboration should be redressed in the IL teaching model for Vietnam's upper secondary schools.

5.2.4 Finance. The study found that a lack of financial support could result in the absence of IL instructions in the two schools and a slow changing from a didactic approach to a constructivist model. Specifically, the low salary made teachers and librarians have no motivation for alternative and teaching activities. According to Hamano (2008) and WB (2014), motivation is one of the key factors contributing to the success of the new teaching approach. This is demonstrated in the following statements: "some teachers persistently refused me when I asked them to do something in the school. They told me that they were too busy with their private classes and why was I forcing them to do such things when their salary was not high. Actually, a young teacher's salary is around 3 million Vietnamese Dong (VND) per month" "and "school librarians' salary is not high, so we do not want to deliver many activities on such an income. Based on the school library assessment criteria, they mainly focus on factors, such as the number of books, computers and book exhibition activities. They do not have criteria related to IL, so why should I have to do it". Educational

33 million VND equal around 100 British Pound or 130 US dollars. 
Development Strategy 2010-2020 indicates that "Regulations and policies are still inconsistent and have not created sufficient incentive to promote the potential of teaching staff". The inconsistency of policies (including salary policy) might significantly affect teachers' contributions.

A lack of information sources, such as books and electronic information sources, that was a consequence of budget cuts might bring disadvantages in the implementation of IL instructions as well as teaching and learning activities. This finding is strengthened by research conducted by Dang (2012) and Vu et al. (2013) who demonstrated that there was a lack of financial support for Vietnam's school libraries. The librarians said that: "my school library receives around 10 million VND per year ${ }^{4}$. It is not enough to purchase new books for students" and "We would give students instructions related to IL if my school library was a digital library. We would have more reliable books and information sources to help students find information. At present, we do not need to teach them such skills because they can find books in the library easily". The analysis of documents found that the libraries did not have adequate financial support for activities. For example, each school library received financial support to acquire only 500 copies of books per year. Furthermore, the library statistics indicated that there was an absence of electronic information resources. The number of books in School B's library and School C's library was 11,683 and 2,312, respectively. They mainly acquired story books, textbooks, examination preparation books and professional books. As shown in the library reports, School B's library stopped using the library software because of budget cuts. In addition, restriction in the application of IT resulted in spending more time than usual to complete the library works. Similarly, School C's library showed that they stopped using the library software from the academic year 2014-2015 and delivering several services due to budget cuts. It is assumed that financial issues are macroscopic matters that the research cannot thoroughly settle. Issues related to information resources and funding are out of control of educational institutions and the researcher. It is recommended that IL instructions can start with free information sources and online search engines.

5.2.5 Students' awareness of information literacy. The study found that not all students were aware of the role of IL to their own learning. Thus, they did not have motivation to develop their IL. This could be a challenge of moving from a didactic approach to a constructivist model. Cognitive elements are pervasive in IL models. However, Bundy

${ }^{4} 10$ million VND equal around 330 British Pound or 450 US dollars. 
(1999) indicates that students' information awareness has not been well developed by the time they move in to college and university education. IL programmes need to concentrate on "fundamental task of shifting the youngsters' attitudes and changing their mindsets" (Pickard et al., 2014, p. 8). In this study, students were not willing to take part in activities that could develop their IL, as said by one of the librarians, "as from this year, my school library will no longer organize a library introduction class because students refuse to go to the class. Students who want to read books can borrow books in the library". One of the students states that: "I think that if you provide an IL course to students, they will give time for private classes rather than the IL course". The students did not highly value the importance of IL "IL is also unnecessary because it does not affect my life too much" and "I do not think that IL is important for us to pay much attention to it, because we have been taught by teachers what we should learn". Students did not highly appreciate the importance of IL to their learning achievement. They were still in favour of the teacher-centred study environment. It is suggested that factors related to students' awareness/cognition should be involved in the IL teaching model in Vietnam's upper secondary schools.

\subsubsection{Support from family. There is evidence that students' family could have} positive impact on the development of their children's IL and their learning. Students increasingly prefer to make use of people (e.g. family, friends and teachers) when searching for information (Smith and Hepworth, 2007). Evidence suggests that library anxiety and uncertainty may be one of the reasons for these young people making use of people when undertaking a search (Smith and Hepworth, 2007). One of the students said that: "my parents often introduce good books and websites to me to help me obtain useful information". There is evidence that parents' IT knowledge has a positive influence on students (Duffy et al., 2010). On the contrary, Chang et al. (2012) revealed that students' ethics scores were negatively affected by their father's highest educational qualification. Research indicates that there is an impact of students' family/parents to their IL development. It could be either a negative or positive impact. In the context of this study, support from family positively affected the development of students' IL.

Parents not only affects the development of IL but also influence changing Vietnam's education culture. One of the administrators said that "not all families are interested in the school's educational policies. Some families even do not allow their children to allow their children to use the computer even though they have it". This view was reinforced by one of the teachers, as follows "If parents can control their children, students will study very well and make an effort to search for more information". They believed that family support could 
affect students' learning in general and IL in particular. Students who received more attention from their family would be motivated to engage with information and develop the necessary skills to support their learning. As mentioned in the context of the study, the desire and value of family has created a lot of pressure for students. Lack of understanding of the new learning and teaching approach and lack of support from family could prevent students from developing new ways of learning. From what has been discussed above, an idea of involving parents in an IL intervention for Vietnamese upper secondary students has emerged.

\section{An information literacy teaching model for Vietnam's upper secondary schools}

Here the study introduces an IL teaching model which offers a framework to Vietnam's schools to design, develop and deliver IL programmes (Figure 3). The model addresses issues surrounding factors affecting the development of IL teaching, as discussed earlier. The expanded AASL model is also included.

\footnotetext{
“Insert Figure 3. Information literacy teaching model for Vietnam's upper secondary schools here"
}

The model begins with "WHAT", the school takes the initial step of identifying what needs to be taught to students regarding IL. It includes the expanded AASL model proposed. Its standards and indicators can be used as a guideline to design IL instructions.

This is followed by, "WHO", which primarily concentrates on issues surrounding stakeholders, such as professionals, students and their family. As discussed earlier, cognitive (awareness) and affective (motivation) elements directly affect the development of IL programmes. Specifically, the study reveals that students had a lack of awareness of IL and a lack of motivation to develop their IL. Cognitive and affective elements also have a great effect on delivering IL instructions among school administrators, teachers and librarians. Thus, the two components are recommended as an essential part of the model.

It is suggested that staff development and collaboration should receive attention of schools in order to ensure the success of IL programmes. Staff development is required to improve professionals' IL teaching capability. The collaboration between teachers, librarians and administrators is also emphasised to ensure the long-term development of IL initiatives. Furthermore, the support from family can motivate students to develop their IL more effectively. 
The third part of the model, "HOW", indicates how to implement an IL programme. Students' IL and IL initiatives cannot be developed effectively if the didactic approach in teaching is still used in the education system. The model encourages the use of the projectbased learning approach which is being implemented in the education system in Vietnam. This approach should be followed by an appropriate learning outcome assessment strategy. Thoroughly employing the project-based learning approach and an appropriate learning assessment strategy may help schools solve problems related to time pressure.

\section{Conclusion}

This research provides an insight into the practice of IL teaching and learning in Vietnam's upper secondary schools. The development of IL programmes in Vietnam's high schools faces many challenges that can be encountered across educational institutions of both developing and developed countries, such as lack of IL programmes, teaching method, resources, collaboration, teaching capability and cognitive readiness of professionals, time pressure, students' awareness of IL and support from family. Nevertheless, contextual issues surrounding the absence of IL programmes, teaching method, lacking resources and time pressure are noticeable issues in Vietnam. These issues need to be addressed to promote the development of IL programmes and the constructivist approach in teaching and learning.

There is a keen interest in how the suggested IL model might affect students' learning in Vietnam's upper secondary schools. It is suggested that a long-term study should be conducted to explore the long-lasting impact of the model. This research involved the participation of 16 interviewees from two upper secondary schools in Vietnam. This number is considered low. A future study should be carried out with a larger sample of schools and interviews to provide a more comprehensive picture of teaching and learning IL in upper secondary schools in the country.

\section{References}

AASL (2007), Standards for the 21st-Century Learner, American Library Association, Chicago.

Accardi, M., Drabinski, E. and Kumbier, A. (2014), Critical library instruction: theories and methods, Library Juice Press, Duluth. 
Bundy, A. (1999), "Information literacy: the 21st-century educational smartcard", Australian Academic \& Research Libraries, Vol. 30 No. 4, pp. 233-250.

Central Committee of the Communist Party of Vietnam (2013), Resolution of the 11th Congress of the Communist Party No. 29-NQ/TW on fundamentally and comprehensively renovating education and training, Central Committee of the Communist Party of Vietnam, Hanoi, available at: http://thuvienphapluat.vn/vanban/Thuong-mai/Nghi-quyet-29-NQ-TW-nam-2013-doi-moi-can-ban-toan-diengiao-duc-dao-tao-hoi-nhap-quoc-te-212441.aspx (accessed 05 December 2018).

Chang, Y., Zhang, X., Mokhtar, I., Foo, S., Majid, S., Luyt, B. and Theng, Y. (2012), "Assessing students' information literacy skills in two secondary schools in Singapore", Journal of Information Literacy, Vol. 6 No. 2, pp. 19-34.

Dang, A. (2011), Private tutoring in Vietnam: a review of current issues and its major correlates, World Bank, Washington DC.

Dang, U. (2012), "Country update: Vietnam (April 2011-April 2012)", paper presented at the 20th Conference of Directors of National Libraries of Asia and Oceania (CDNL-AO): National Heritage: Preservation and Dissemination, 28 May, Kuta, Bali-Indonesia, available at: http://www.ndl.go.jp/en/cdnlao/meetings/pdf/CR2012_Vietnam.pdf (accessed 20 March 2018).

Dorner, D. (2017), "Chapter E. Region: Asia/Oceania", in ACRL (Ed.), Global Perspectives on Information Literacy: Fostering a Dialogue for International Understanding, Association of College and Research Libraries, Chicago, pp. 47-59.

Dorner, D. and Gorman, G. (2006), "Information literacy education in Asian developing countries: cultural factors affecting curriculum development and programme delivery", IFLA Journal, Vol. 32 No. 4, pp. 281-293.

Duffy, A., Liying, T. and Ong, L. (2010), "Singapore teens' perceived ownership of online sources and credibility", First Monday, Vol. 15 No. 4, available at: http://firstmonday.org/ojs/index.php/fm/article/view/2197/2484 (accessed 10 March 2018).

Hamano, T. (2008), "Educational reform and teacher education in Vietnam", Journal of Education for Teaching, Vol. 34 No. 4, pp. 397-410. 
Layder, D. (1993), New strategies in social research: an introduction and guide, Polity Press, Cambridge.

Limberg, L., Sundin, O. and Talja, S. (2012), "Three theoretical perspectives on information literacy", Human It, Vol. 11 No. 2, pp. 93-130.

Lloyd, A. (2012), "Information literacy as a socially enacted practice; Sensitising themes for an emerging perspective of people-in-practice", Journal of Documentation, Vol. 68 No. 6, pp. 772-783.

London, J. (2011), Education in Vietnam, Institute of Southeast Asian Studies ISEAS, Singapore.

Mayes, T. and de Freitas, S. (2013), “Technology-enhanced learning: the role of theory", in Beetham, H. and Sharpe, R. (Eds.), Rethinking Pedagogy for A Digital Age:

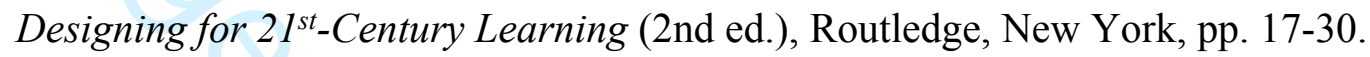

MOET (2014), Education for All 2015 National Review Report: Vietnam, available at: https://unesdoc.unesco.org/ark:/48223/pf0000232770 (accessed 05 December 2018).

Nguyen, N. and Williams, P. (2016), "An ICT supported sociocultural approach to improve the teaching of physics", Asia-Pacific Science Education, Vol. 2 No. 1, pp. $1-21$.

Nguyen, T. M. H. and Hall, C. (2017), "Changing views of teachers and teaching in Vietnam", Teaching Education, Vol. 28 No. 3, pp. 244-256.

Nguyen, T. Q. T. (2015), "The influence of traditional beliefs on Vietnamese college lecturers' perceptions of face", Journal of Education for Teaching, Vol. 41 No. 2, pp. 203-214.

Nguyen, V. (2013), Orienting to pedagogical innovation: a case study of Vietnamese teachers' beliefs and practices regarding task-based language teaching, thesis, Hanilton, New Zealand, University of Waikato, available at: http://researchcommons.waikato.ac.nz/handle/10289/7433 (accessed 9 March 2018).

Norgaard, R., Arp, L. and Woodard, B. S. (2003), "Writing information literacy contributions to a concept", Reference and User Services Quarterly, Vol. 43 No. 2, pp. 124-130. 
Peeraer, J. and Van Petegem, P. (2011), "ICT in teacher education in an emerging developing country: Vietnam's baseline situation at the start of 'The Year of ICT', Computers \& Education, Vol. 56 No. 4, pp. 974-982.

Pickard, A., Gannon-Leary, P. and Coventry, L. (2011), "The onus on us? Instilling trust in our users", Library and Information Research Journal, Vol. 35 No. 111, pp. 87104.

Pickard, A., Shenton, A. and Johnson, A. (2014), "Young people and the evaluation of information on the World Wide Web: principles, practice and beliefs", Journal of Librarianship and Information Science, Vol. 46 No. 1, pp. 3-20.

Prime Minister (2011), Decision No. 1216/QĐ-TTg on approving the project "Developing Human Resources in Vietnam 2011-2020", Prime Minister of Vietnam, Hanoi, available at: http://thuvienphapluat.vn/van-ban/Lao-dong-Tien-luong/Quyet-dinh1216-QD-TTg-phe-duyet-Quy-hoach-phat-trien-nhan-luc-Viet-Nam-126974.aspx (accessed 05 December 2018).

Shenton, A., Pickard, A. and Johnson, A. (2014), "Information evaluation and the individual's cognitive state: some insights from a study of British teenaged users", IFLA Journal, Vol. 40 No. 4, pp. 307-316.

Smith, J. (2013), "Secondary teachers and information literacy (IL): teacher understanding and perceptions of IL in the classroom", Library and Information Science Research, Vol. 35 No. 3, pp. 216-222.

Smith, M. and Hepworth, M. (2007), "An investigation of factors that may demotivate secondary school students undertaking project work: Implications for learning information literacy", Journal of Librarianship and Information Science, Vol. 39 No. 1, pp. 3-15.

UNESCO (2013a), Global Media and Information Literacy Assessment Framework: Country readiness and competencies, UNESCO, Paris.

UNESCO (2013b), ICT in education policy, infrastructure and ODA status in selected ASEAN countries, Asia and Pacific Regional Bureau for Education, Bangkok.

UNESCO (2015), Education for All 2000-2015: achievements and challenges; EFA global monitoring report 2015, available at: https://en.unesco.org/gemreport/report/2015/education-all-2000-2015-achievements-and-challenges (accessed 05 December 2018). 
Vu, N., Pham, R. and Le, H. (2013), "Investment to Vietnam's libraries: real situations and solutions", Journal of Information and Documents, Vol. 4, pp. 3-12.

Walton, G. and Cleland, J. (2013), "Becoming an independent learner", in Secker, J. and Coonan, E. (Eds.), Rethinking Information Literacy: A Practical Framework for Supporting Learning, Facet, London, pp. 13-26.

Walton, G. and Hepworth, M. (2013), "Using assignment data to analyse a blended information literacy intervention: a quantitative approach", Journal of Librarianship and Information Science, Vol. 45 No. 1, pp. 53-63.

Webber, S. and Johnson, B. (2006), "Working towards the informayion literate university", in Walton, G. and Pope, A. (Eds.), Information Literacy: Recognising the Need, Chandos Publishing, Oxford, pp. 47-58.

World Bank (2011), Vietnam: high quality education for all by 2020, available at: http://documents.worldbank.org/curated/en/416151468320084130/Overviewpolicy-report (accessed 05 December 2018).

World Bank (2014), Skilling up Vietnam: preparing the workforce for a modern market economy - Vietnam Development Report 2014, available at:

http://documents.worldbank.org/curated/en/283651468321297015/Skilling-upVietnam-preparing-the-workforce-for-a-modern-market-economy (accessed 05 December 2018). 


\begin{tabular}{|c|c|c|}
\hline CONTEXT - & \multirow{5}{*}{\multicolumn{2}{|c|}{$\begin{array}{l}\text { Vietnam: } \\
\begin{aligned} \text { - } & \text { Cultural and social context } \\
\text { - } & \text { Educational context } \\
\text { - } & \text { School library system } \\
\text { - } & \text { Digital access }\end{aligned}\end{array}$}} \\
\hline MACRO & & \\
\hline \multirow[t]{3}{*}{ ENVIRONMENT } & & \\
\hline & & \\
\hline & & \\
\hline \multirow{2}{*}{ SETTING } & \multicolumn{2}{|c|}{ Intermediate social organization } \\
\hline & $\begin{array}{l}\text { Case } 1 \text { - School B } \\
(1,146 \text { students })\end{array}$ & $\begin{array}{l}\text { Case } 2 \text { - School C } \\
\text { (981 students) }\end{array}$ \\
\hline $\begin{array}{l}\text { SITUATED } \\
\text { ACTIVITY }\end{array}$ & Learning & Learning \\
\hline SELF & $\begin{array}{l}\text { IL development - } \\
\text { students, librarians, } \\
\text { teachers, } \\
\text { administrators }\end{array}$ & $\begin{array}{l}\text { IL development - } \\
\text { students, librarians, } \\
\text { teachers, } \\
\text { administrators }\end{array}$ \\
\hline
\end{tabular}

Figure 1. The context of two schools at both macro and micro environment 


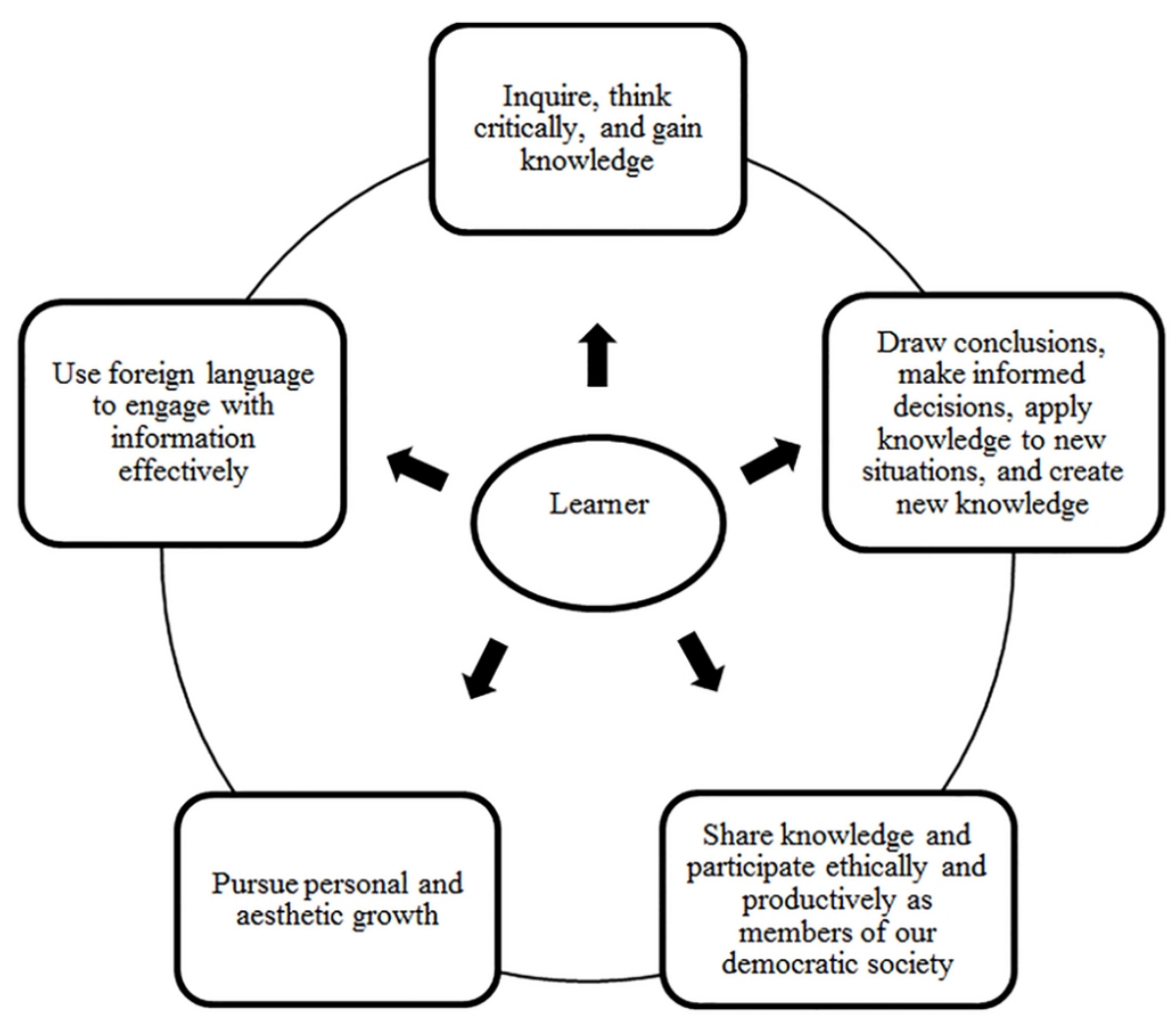

Figure 2. The expanded AASL model $198 \times 167 \mathrm{~mm}(150 \times 150 \mathrm{DPI})$ 


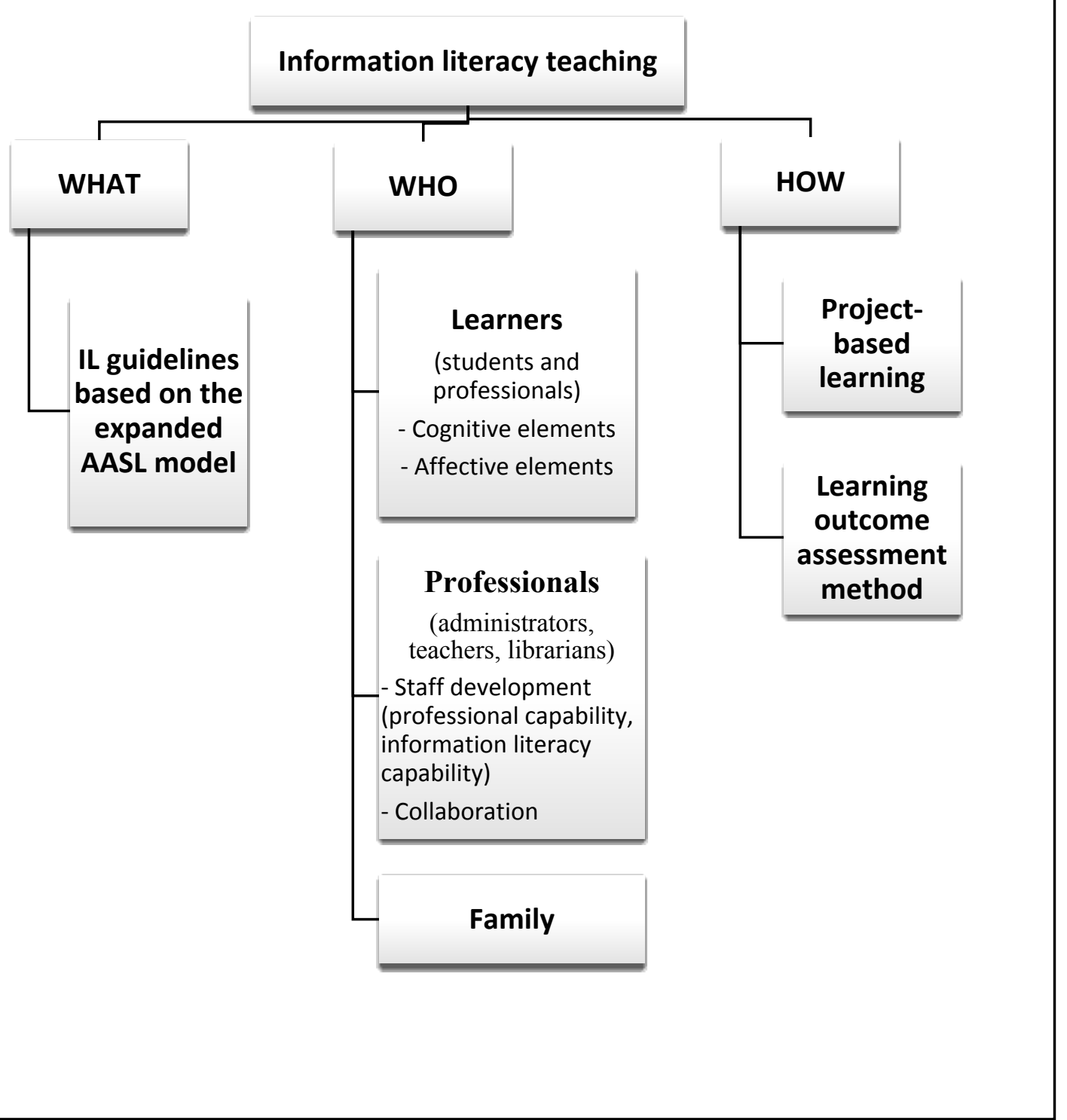

Figure 3. Information literacy teaching model for Vietnam's upper secondary schools 